\title{
Entre uniformes e espartilhos - os trajes de ciclismo no século $X I X$, da Europa a Porto Alegre
}

Between uniforms and corsets - cycling suits in 19th century, from Europe to Porto Alegre 


\section{Natália de Noronha Santucci ${ }^{1}$}

ORCID: https://orcid.org/0000-0002-2907-7592

[resumo] Este texto contém um panorama da relação entre as modas de vestuário e as modas de atividades físicas ligadas ao ciclismo. Serão comentados os momentos que draisianas, velocípedes e bicicletas estiveram em voga, e as soluções encontradas no vestuário para utilizá-los, assim como a codificação do uso de algumas peças de roupa e objeções enfrentadas. As práticas adotadas pelos clubes de ciclismo que existiram em Porto Alegre entre o fim do século XIX e o início do XX serão o alicerce para a elaboração de comparações entre o Brasil e a Europa.

[palavras-chave] Moda Esportiva. História da Moda. Ciclismo. Século XIX.

[abstract] This paper presents an overview of the correlations between clothing fashions and the fashions of physical activities related to cycling. Our comments will span from when draisiennes, velocipedes, and bicycles were popular, as well as the solutions found in terms of clothes to use them, the codification of the use of some pieces of clothing, and objections which were faced. The practices adopted by the cycling clubs that existed in Porto Alegre between the end of the nineteenth century and the beginning of the twentieth will be the foundation for the elaboration of comparisons between Brazil and Europe.

[keywords] Sportswear. Fashion History. Cycling. 19th century.

Recebido em: 15-06-2019

Aprovado em: 14-07-2019

\footnotetext{
${ }^{1}$ Mestra em História pela Pontifícia Universidade Católica do Rio Grande do Sul (PUCRS). Pesquisadora do grupo História da Arte e Cultura de Moda vinculado à Universidade Federal do Rio Grande do Sul (UFRGS). nataliasantucci@gmail.com. http://lattes.cnpq.br/5694944404847749.
} 


\section{Antecedentes}

Durante o século XVIII, na Europa, foram estabelecidas as bases de muito do que a sociedade ocidental desenvolveria entre o século XIX e o início do XX, desde as novas concepções de higiene e saúde, acompanhadas pela difusão da roupa branca ${ }^{2}$, passando pela roupa revolucionária ${ }^{3}$ e sua aspiração à liberdade e à igualdade, até a fascinação dos europeus por produtos e roupas do Oriente (ROCHE, 2007; SENNETT, 1988; WARNER, 2006). Mesmo antes do século XIX, a aristocracia britânica, por exemplo, já demonstrava favoritismo pelo tiro e pela caça - o cavalo, o campo e a prática de jogos ao ar livre eram apreciados (LAVER, 1953) -, o que dotou as roupas de "certa sobriedade puritana e inovações de caráter esportivo"(BOUCHER, 2010, p. 290).

A subsequente ampliação do interesse por práticas físicas e a criação de novos espaços de sociabilidade, como os clubes recreativos e esportivos, deram impulso a demandas por trajes específicos para diversas atividades. Essa imbricação pode ser esclarecida pela perspectiva da moda como um fenômeno relacionado à adoção temporária de comportamentos, à sociabilidade e à validação coletiva, percebido sobretudo por meio das roupas e dos itens de aparência, mas abrangendo todas as esferas da vida em sociedade (SPROLES citado por MILLER; MCINTYRE; MANTALA, 1993; LIPOVESTKY, 2009). A mesma noção permite compreender ainda o abandono seletivo de algumas dessas práticas, enquanto outras são continuadas e assumem outro papel social.

A partir do cruzamento entre imagens, notícias e referências históricas, os valores culturais e a relação dos trajes de ciclistas com a moda serão abordados. Serão destacados dois clubes que surgiram em Porto Alegre no fim do século XIX, a partir dos quais as roupas utilizadas por homens e mulheres no contexto do ciclismo, suas semelhanças e diferenças com outras regiões, serão comentadas.

\section{Em movimento}

Em 1817, o alemão Karl von Drais inventou um veículo de duas rodas, impulsionado pelos pés. Posteriormente conhecido como draisiana, o artefato foi introduzido na Inglaterra em 1819, por um construtor de coches de Londres, Denis Johnson, em uma versão mais leve e mais barata, chamada de Pedestrian Hobbyhorse, que poderia dar um novo alcance

\footnotetext{
2 Ver ROCHE, Daniel. A cultura das aparências: uma história da indumentária (séculos XVII-XVIII). Tradução Assef Kfouri. São Paulo: Editora Senac São Paulo, 2007.

3 Sennett (1988) indica que, nos primeiros anos após a Revolução, as roupas deveriam tornar o corpo neutro, eram uniformes sem ornamentação para simbolizar a liberdade e a igualdade.
} 
aos esportes ${ }^{4}$ nos quais pedestres apostavam contra o tempo (ACKERMANN, 1819). Ilustrações da época mostram tanto homens quanto mulheres utilizando o artefato, trajando a moda corrente. Também é possível notar que a versão feminina possuía uma curvatura, que permitia acomodar as saias - adaptação que também seria vista nas bicicletas femininas do fim do século.

\section{FIGURA 1 - HOBBYHORSES MASCULINOS}

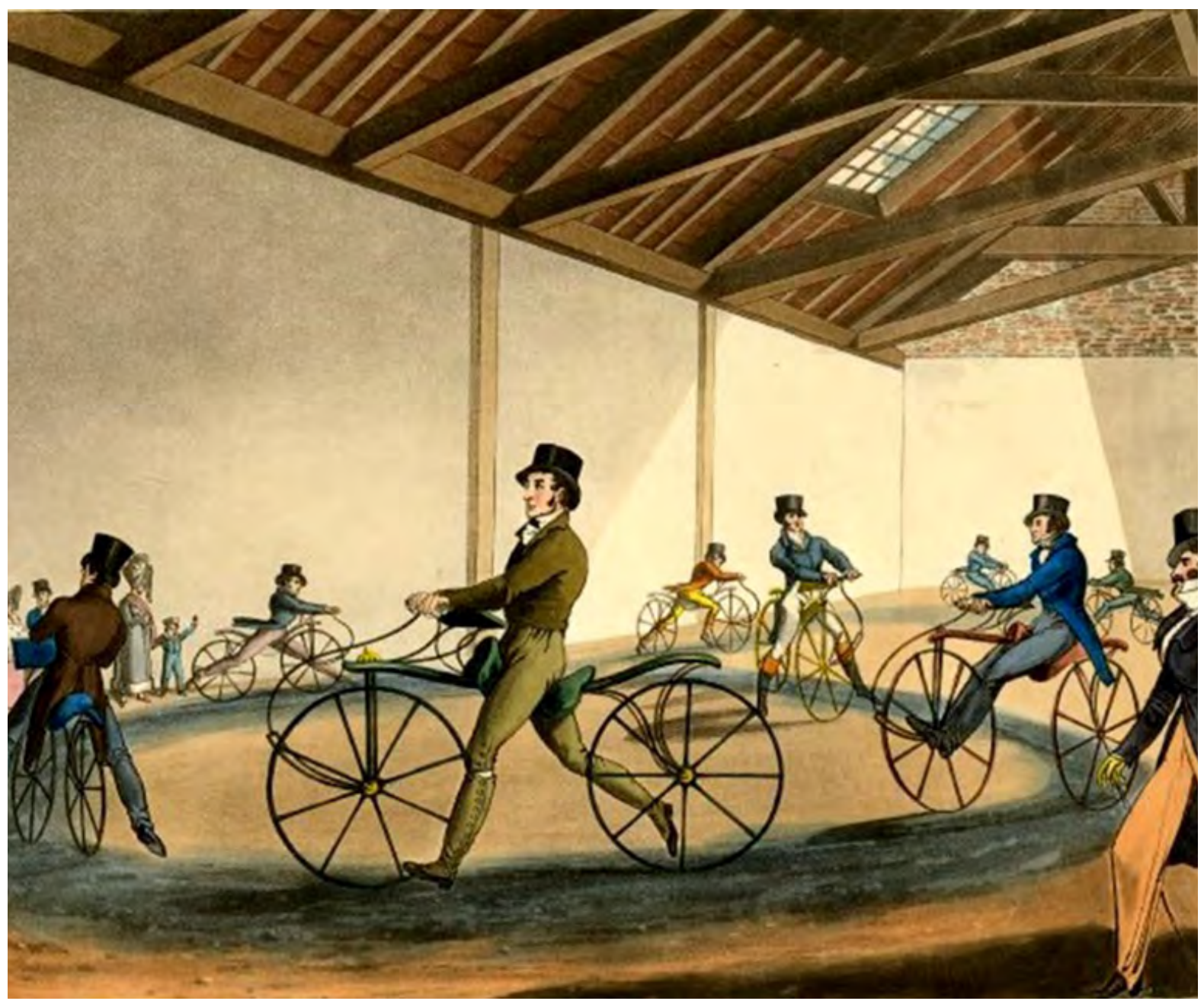

FONTE: Ackermann's Repository, 10 mar. 1819. Acervo: Museu Britânico, Londres.

\footnotetext{
${ }^{4}$ Do original "Pedestrian wagers against time have of late been much the hobby of the English people, and this new invention will give new scope for sport of that sort" (ACKERMANN, 1819, p. 109, grifo meu). Embora as diferenças entre esporte e recreação possam ser discutidas, a aposta de corridas foi apontada como um esporte pelo catálogo.
} 


\section{FIGURA 2 - HOBBYHORSES FEMININOS}

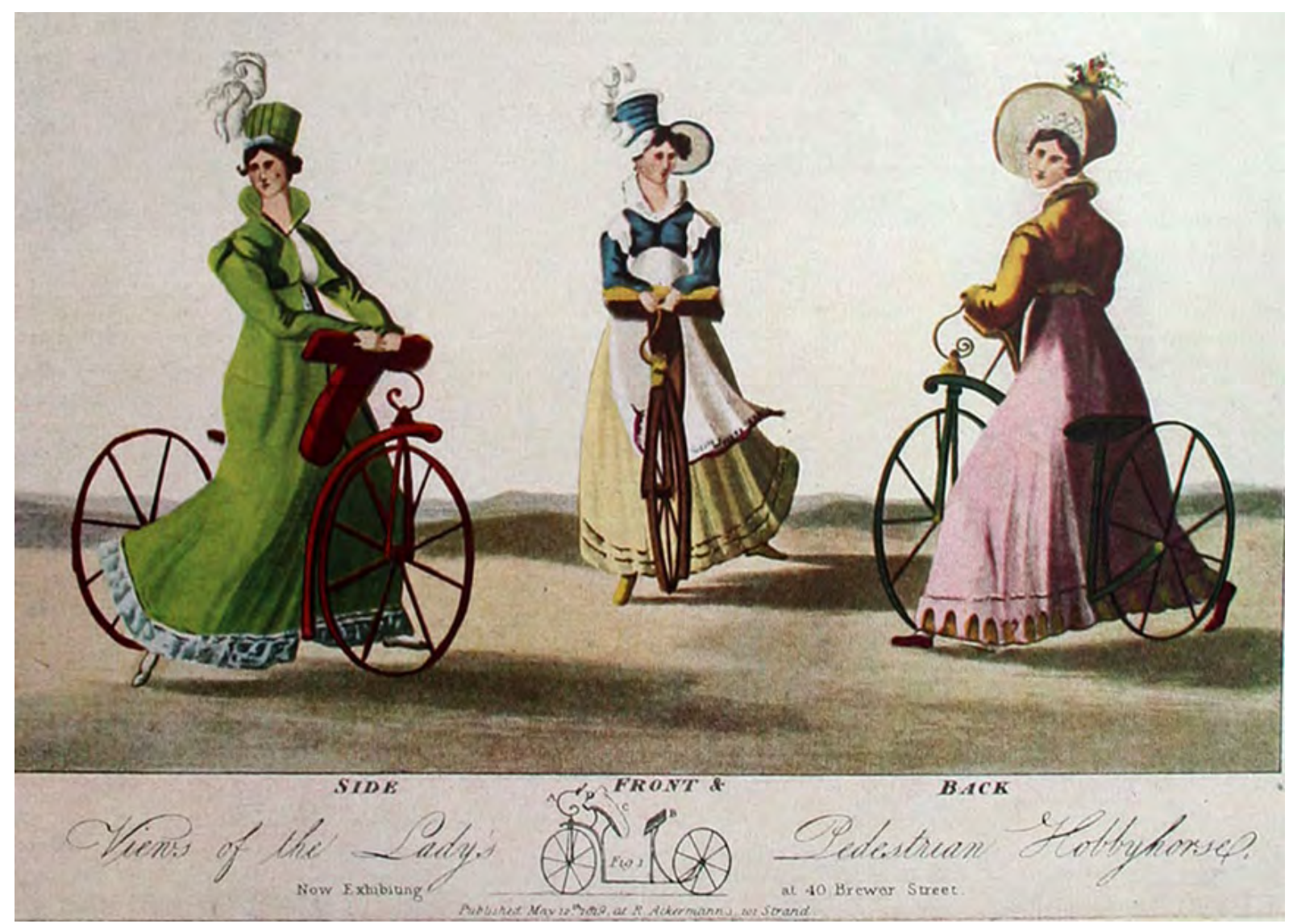

FONTE: Ackermann's Repository, 12 maio 1819. Acervo: Museu da Ciência, Londres5.

Se o vestuário em voga no primeiro quarto do século XIX concedia maior liberdade de movimento aos corpos, nos anos seguintes, os padrões foram se tornando mais complexos, reduzindo essa mobilidade. Paralelamente, em 1821, as draisianas já haviam praticamente desaparecido - de acordo com John Pinkerton, foram "simplesmente uma moda dos ricos, e modas vêm e vão em uma certa altura” (PINKERTON, 2001 citado por WILSON, 2004, p. 4).

James Laver (1953) pontua que as roupas da metade do século, sobretudo as masculinas, tiveram origem no vestuário esportivo de outrora, o que compeliu a elaboração de novas roupas esportivas, pois essas atividades demandaram algo mais simples que o vestuário cotidiano. A propagação das práticas físicas teria êxito em promover modificações na indumentária das classes altas, mais do que as sugestões de movimentos sociais. Essas últimas poderiam parecer um desafio aos códigos estabelecidos muito além do que o cidadão médio estava disposto a empreender, pelos mais diversos motivos (BOUCHER, 2010; CRANE, 2006).

Dito isso, é indispensável apresentar Amelia Bloomer que, em meados do século, fazia parte do Movimento de Temperança americano, uma organização puritana que pregava

Ver também ilustração Lady's pedestrian hobby-horse, George Arents Collection, The New York Public Library. Disponível em: http://digitalcollections.nypl.org/items/510d47de-4b76-a3d9-e040-e00a18064a99. Acesso em: 14 jun. 2019. 
a elevação moral e combatia o alcoolismo. Boucher e Laver pontuam que Bloomer fracassou em sua tentativa de influenciar o vestuário de sua época, porém, o nome da ativista consolidou-se na História da Moda graças a uma das mais conhecidas propostas de reforma do vestuário, apresentada em 1851, nos Estados Unidos (BOUCHER, 2010; LAVER, 1989). O conjunto usado por Bloomer e suas companheiras era considerado confortável, prático, seguro e bem-arrumado (BLOOMER citada por WARNER, 2006), e seria semelhante ao que se vestia em algumas comunidades religiosas americanas, composto por um corpete simplificado e calças volumosas, cobertas por uma saia abaixo dos joelhos (BOUCHER, 2010; CRANE, 2006). Houve médicos e feministas favoráveis à ideia, mas as mulheres que se dispuseram a usar o traje em público teriam sido assediadas por multidões, geralmente agressivas, o que as teria desencorajado (CRANE, 2006). Revistas, como a inglesa Punch, publicavam charges satíricas "em que homens tímidos estavam totalmente submissos às suas mulheres que usavam calças" (LAVER, 1989, p. 183).

Patricia Campbell Warner (2006) destaca que as calças para mulheres, no feitio das de Bloomer, não apareceram do nada no meio do século apenas para serem rejeitadas por um público de mentalidade estreita, por serem muito novas e chocantes. A ideia já estaria rondando há um bom tempo, mas sua materialização no vestuário feminino diário teria causado todo o problema. A autora indica que, embora os anos 1830 e 1840 tenham sido "fracos" em termos de atividades físicas femininas, a chamada "roupa turca" ou algum tipo de traje leve, com calças visíveis sob a saia, eram recomendados em textos sobre exercícios. Warner ainda cita como exemplo Mulheres de Argel em seu apartamento, de Eugène Delacroix (1834), na qual as figuras centrais são três mulheres usando calças, e que pinturas como esta, mostradas em Paris, teriam sido vistas por pessoas que poderiam influenciar a moda. Pode-se destacar ainda a pintura Mme Bru, cantinière du 7e régiment de hussards, de $1837^{6}$. As cantinières eram mulheres que integravam a infantaria francesa desde o século XVIII, responsáveis pelos alimentos para os soldados (CARDOZA, 2010). Essas figuras estavam presentes na Guerra da Crimeia (18531856), um dos primeiros conflitos a ter uma cobertura fotográfica, realizada por Roger Fenton, que, inclusive, retratou essas mulheres vestindo suas fardas que, aparentemente, já continham calças à mostra desde pelo menos a década de 1830 (CARDOZA, 2010).

Apesar do burburinho causado por Bloomer, roupas voltadas para atividades como a ginástica e os banhos de mar, geralmente descritas remetendo à indumentária oriental, continuaram a ser divulgadas pelas revistas, como as americanas Godey's Lady's Book e Harper's Bazar ${ }^{7}$, nos anos seguintes (SANTUCCI, 2016). Eram roupas que seriam consideradas inaceitáveis em outros contextos, mas que poderiam ser experimentadas na esfera privada ou em espaços isolados (CRANE, 2006).

No fim dos anos 1860, o interesse pelos veículos de duas rodas ganhou novo fôlego, a partir da adição de pedais à roda dianteira da draisiana, promovendo um "entusiasmo selvagem", que se espalhou por países como França, Bélgica, Holanda, Alemanha, Estados

\footnotetext{
${ }^{6}$ Cardoza atribui Mme Bru, cantinière du 7e régiment de hussards ao pintor francês Horace Vernet (1789-1863). Contudo, o Musée de l’Armée Invalides sustenta que o autor é anônimo. Disponível em: https://basedescollections . musee-armee.fr/ark:/66008/1484?posInSet=3\&queryId=041162ef-a157-40ed-8950-51c5fea58fc7. Acesso em: 14 jun. 2019.

A revista começou a ser publicada em 1867. No fim da década de 1920, ganhou mais um "A" no título, tornando-se Harper's Bazaar. Ver: www.harpersbazaar.com/culture/features/a19768/1920s-bazaar-excerpts/. Acesso em: 9 dez. 2019.
} 
Unidos e Grã-Bretanha - “o primeiro boom real da bicicleta estava em andamento” (WILSON, 2004, p. 14-15).

David V. Herlihy (2004) destaca que diante do oferecimento feito pelo francês Michaux de aulas gratuitas para os compradores de velocípedes, que tinha o alto preço como um possível obstáculo à compra, até mesmo mulheres requintadas, vestidas com elegantes roupas de ginástica, apareceram em sua loja prontas e dispostas a pedalar. No retrato de Blanche D’Antigny, o conjunto corresponde a esses modelos "turcos" para atividades físicas, ao mesmo tempo que as cores escuras e o chapéu com pluma rementem aos trajes de equitação da época.

FIGURA 3 - RETRATO DE BLANCHE D'ANTIGNY (1840-1874), ATRIZ

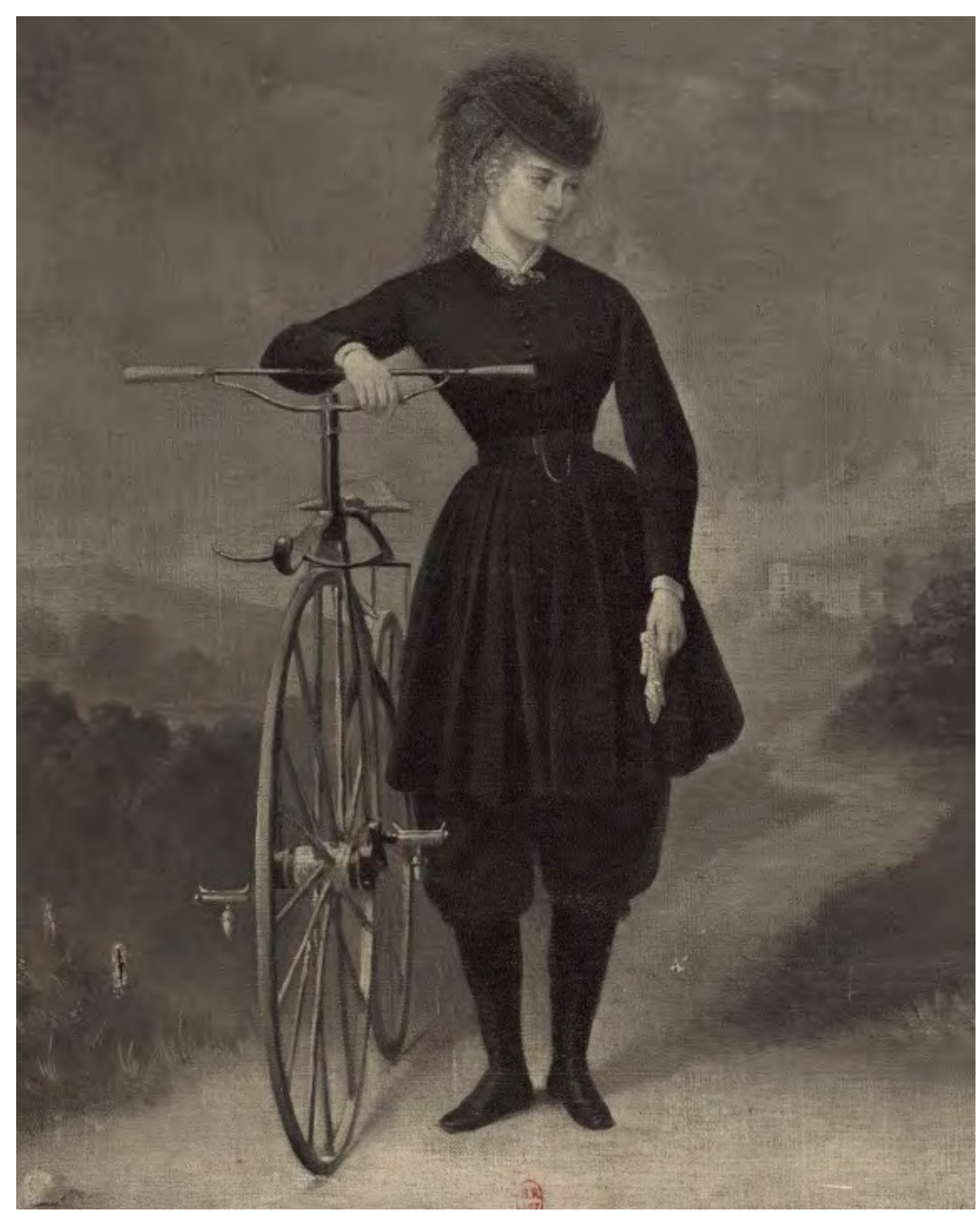

FONTE: BETINET, Maurice [?], 1869. Acervo: Bibliothèque Nationale de France. Disponível em: http:// gallica.bnf.fr/ark:/12148/btv1b85385789. Acesso em: 3 nov. 2016.

Na mesma época, foi anunciada a exibição, nos Estados Unidos, do novo velocípede feminino de B. S. Lawson que, entre outras qualidades, não requeria nenhuma troca de roupa (SANTUCCI, 2016) - mais uma vez, a preocupação em manter as mulheres adequadamente vestidas estimulava a diferenciação na estrutura do veículo. 
Entre os anos 1870 e 1880, homens jovens e abastados teriam predileção por um modelo de velocípede com a roda dianteira alta, também conhecida como Penny Farthing ou Ordinary, que seria promovido por clubes organizados e uniformizados, em estilo militar - o traje para ciclistas concebido pelos ingleses, por exemplo, era composto por "calções justos até o joelho, um paletó muito justo com aspecto militar e um boné pillbox" (LAVER, 1989, p. 205), também semelhante ao que compunha o uniforme de tropas britânicas. 0 Ordinary era considerado viril e de alta velocidade, mas por homens mais velhos e mulheres era percebido como perigoso, o que, somado aos códigos de vestuário da época, afastava esses usuários, mesmo que tivessem capital para adquirir o veículo (WILSON, 2004; PINCH; BIJKER, 2012).

Laver (1989) comenta que o vestuário dos ciclistas ingleses não parece ter sido adotado na França nem na Alemanha, apesar da popularidade da prática nesses países. Entretanto, a uniformização nos clubes e a similaridade com a lógica das fardas é perceptível em imagens como a seguinte.

FIGURA 4 - A CONHECIDA EQUIPE DO RADFAHRER-CLUBS “HANNOVER” DE 1885

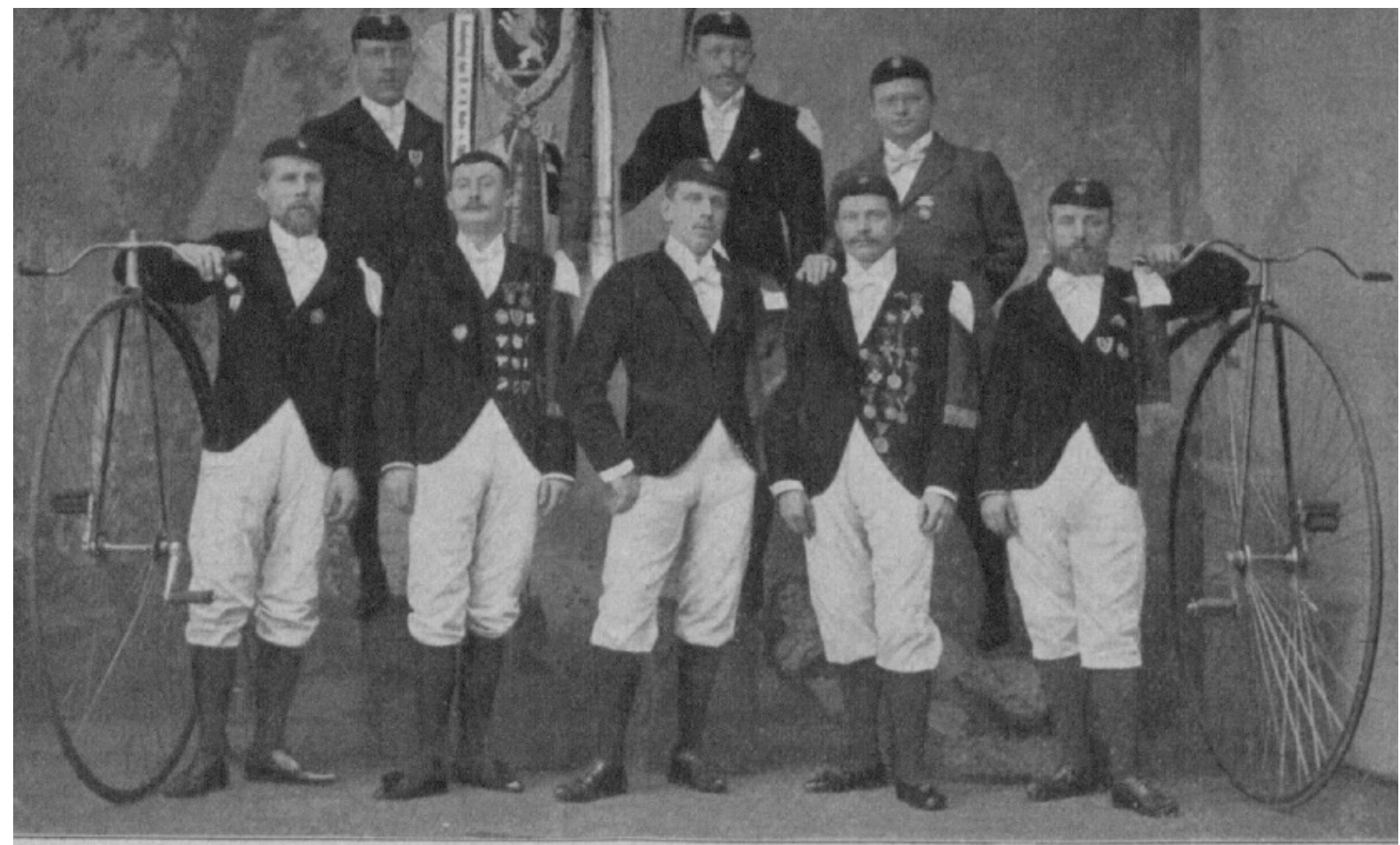

Die bekannte Achter-Hochradreigen-Mannschaft des Radfahrer-Clubs "Hannover" von 1885.

FONTE: Autor desconhecido, c.1885. Sport im Bild, n. 11, 18 mar. 1898, p. 170.

Norbert Elias (1994) indica que, conforme os espaços sociais foram pacificados por meio do "monopólio da força" sob determinadas autoridades, foram criados substitutos em livros e pinturas para perigos e emoções. Essas referências militares em círculos civis possibilitam, ainda, conectar o esporte e a moda a essas substituições.

Sennett comenta que, no fim do século XIX, 
[...] as pessoas haviam decidido amenizar as ansiedades e a opacidade dessa cultura psicológica [do período vitoriano]. Nas roupas, esse processo de desvitorianização parece ter começado na década de 1890, fortalecendo-se nos anos que precederam a Grande Guerra. (SENNETT, 1988, p. 229)

Ao lado dessa mudança de valores, havia o descontentamento demonstrado por intelectuais, feministas e alguns médicos quanto a certos padrões de elegância. Simultaneamente, avolumavam-se os espaços de sociabilidade relacionados a esportes e, entre meados de 1880 e o início de 1890, bicicletas mais parecidas com as que existem até hoje começaram a ser fabricadas. Esses fatores podem ter contribuído para a difusão do veículo entre as mulheres, apesar da adequação do vestuário permanecer como um desafio. As bicicletas de "quadro fechado", também conhecido como "diamante", impediam que mulheres de saias as montassem, o que ocasionou testes de várias estruturas diferenciadas, até que um modelo que possuía apenas o tubo inferior foi consolidado (SANTUCCI, 2016).

Nas províncias, um dos propulsores para o surgimento de clubes esportivos seria o ímpeto da modernização e da civilização dos hábitos em conformidade com os modelos europeus. A assimilação desses padrões ocorreria a partir de uma relação de desigualdade, na qual a sociedade europeia desempenharia o papel de uma "classe alta", disseminando suas condutas "civilizadas" por meio de pequenos grupos dirigentes e elites dessas províncias, que estariam em níveis inferiores (ELIAS, 1994). Isso concederia uma característica de moda às práticas promovidas, inclusive sendo frequentemente nomeadas pela imprensa como "o esporte da moda" (SANTUCCI, 2016).

\section{Lazer e solenidade}

Foi entre as décadas de 1850-1870 que diversas práticas físicas começaram a reunir adeptos em cidades brasileiras, como Rio de Janeiro, São Paulo e Porto Alegre. Os primeiros velocípedes chegaram ao país no fim da década de 1860. Eram produtos caros, europeus ou estadunidenses, e permaneceram como objetos de luxo até mesmo nos anos 1890, ainda que importados em maior quantidade (LICHT, 2002; MELO, 2009; SCHETINO, 2007). Nos anos 1880, os garotos da família Prado, precursores do ciclismo em São Paulo, já possuíam velocípedes, e alguns clubes do Rio de Janeiro organizavam corridas já em 1885 (GAMBETA, 2013; SCHETINO, 2007). Sete anos depois, seriam anunciadas quatro corridas em velocípedes no Campo da Redenção, em Porto Alegre, no mesmo ano que apareceu a primeira associação amadora de ciclismo em São Paulo (PRADO AVENIDA. A Federação, Porto Alegre, 5 set. 1892, p. 2, citado por GAMBETA, 2013).

Ainda que distante da capital nacional, Porto Alegre seria considerada, em poucos anos, "o centro do ciclismo brasileiro" - um de seus clubes, a União Velocipedica de Amado$\mathrm{res}^{8}$, agregaria mais de mil sócios, e talvez tivesse a melhor pista do país. Algumas fotografias de seus ciclistas chegaram a circular em jornais do Rio de Janeiro. Na cidade, o ciclismo

\footnotetext{
${ }^{8}$ A grafia original do nome da associação foi mantida.
} 
como uma prática da moda resultou em dois grandes clubes em meados dos anos 1890 - a citada União Velocipedica foi fundada em 1895, e as últimas menções a ela, encontradas na imprensa local, são de 1907. Em 1896, integrantes da comunidade teuto-brasileira e membros do Ruder Verein Germania (Clube de Remo Germânia) criaram a Radfahrer Verein Blitz (Clube Ciclista Relâmpago), mencionada até 1911. Entre 1898 e 1901, o interesse pelos passeios, corridas e festas realizados pelos clubes de ciclismo porto-alegrenses teve seu auge, perdendo força nos anos seguintes, possivelmente por causa de brigas entre os clubes e de poucas novidades apresentadas nas competições, ao mesmo tempo que novos interesses desembarcavam na cidade (SANTUCCI, 2016).

Com o surgimento desses clubes esportivos, a exemplo dos que existiam no Hemisfério Norte, e das disputas entre eles, os uniformes e outras formas de identificação tornaram-se relevantes. Observando que "por séculos têm-se usado uniformes (militares, policiais ou religiosos) para impor identidades sociais aos indivíduos de forma mais ou menos voluntária" (CRANE, 2006, p. 22), que "gestos e roupas especiais para a prática de exercícios físicos e esporte oscilam entre uma ideia de eficácia técnica, de moda, de pertencimento de classe, de códigos de gênero, e de valorização das aparências, ou talvez de fabricação de novas aparências" (SOARES, 2011, p. 29) e que "identidade é um dos conceitos seminais para se descrever a função da moda" (SVENDSEN, 2010, p.158), o papel da adoção de trajes específicos e uniformes para os associados fica bastante claro. A aparência dos homens era normatizada, assim como a das mulheres, ainda que as variações de moda fossem mais sutis e houvesse certa antipatia pelos trajes masculinos para o ciclismo, embora possivelmente menos acalorada do que a direcionada aos calções femininos.

Alguns admittem a bicycleta, mas não concordam com o uniforme correspondente, e é assim que todos começam rejeitando completamente o calção e o bonet. [...]

Não é um luxo, nem tambem uma macaquice nossa, o uso da roupa propria. É, sim, uma necessidade. 0 ciclysta precisa, qual gymnasta na arena, estar lepido e apto para pular e saltar ligeiramente, quando quiser, e não é de calça comprida e botas de sola grossa que o poderá fazer. Que graça teria vermos um sujeito nestas condições a fazer gymnastica. E o cyclismo não é outra cousa. (CORREIO DO POVO, 26 mar. 1899, citado por LICHT, 2002, p. 37)

Alguns materiais eram recomendados por suas propriedades físicas - os tecidos de lã, pela condução de umidade e calor, o couro de gamo para as luvas, para a proteção das mãos. Meias de lã e chapéus de feltro eram indicados para o inverno, enquanto meias de algodão e chapéus de palha para o verão (A FEDERAÇÃO, Porto Alegre, 17 ago. 1899, p. 2.). Há anúncios de peças dentro dessas especificações à venda em Porto Alegre nos primeiros anos de 1900 (A FEDERAÇÃO, 20 jun. 1900; 19 abr. 1901; 8 dez. 1902, 26 mar. 1904).

Além dessas determinações gerais, havia as exigências dos clubes para que seus membros portassem suas carteiras de sócio ou distintivos a fim de ter acesso aos próprios velódromos, ou a eventos nos quais eram visitantes, além de vestirem seus uniformes, que começaram a ser utilizados em 1898 (SANTUCCI, 2016). 
A maior parte das fotografias identificadas do período mostram os membros da União, mas, a partir do cruzamento com o trecho abaixo, acredita-se que a imagem a seguir também apresente integrantes da Blitz, diferenciados pela tonalidade das camisas, mais escuras do que as dos demais ciclistas.

Entrando no velódromo os cyclistas da União percorreram a pista e descreveram uma espiral na pelouse foi reunindo-se ao centro onde formou. A Blitz seguindo os mesmos movimentos tomou posição à frente da União. (A FEDERAÇÃo, Porto Alegre, 20 nov. 1899, p. 2)

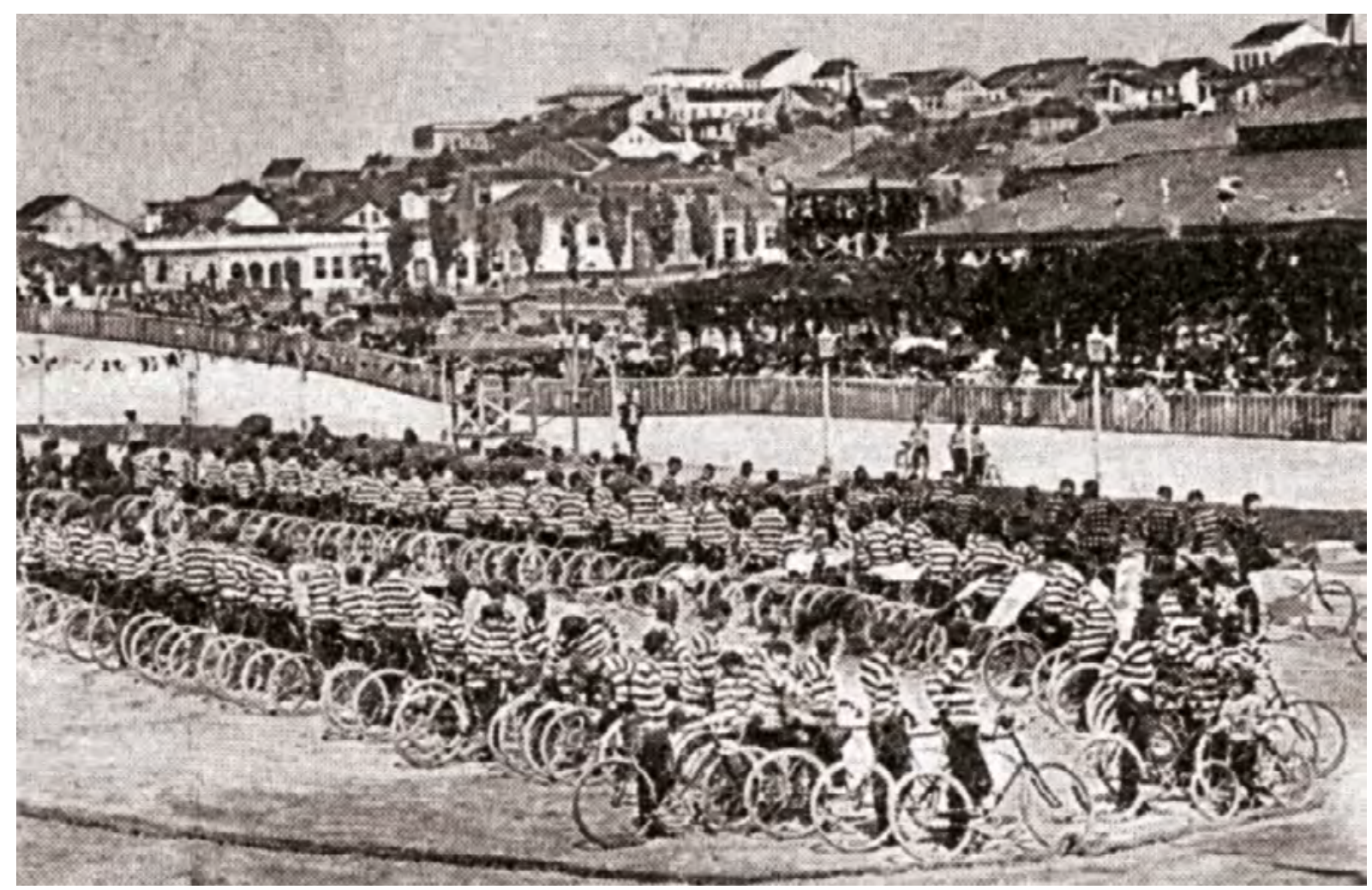

FONTE: LUNARA [?], [1899]. Revista do Globo, ano 8, n. 190, 5 set. 1936, p.15. Acervo: Delfos/PUCRS. ${ }^{9}$

\footnotetext{
Denise Stumvoll ressalta uma nota em A Federação (23 nov. 1899, p. 2), na qual a autoria de Lunara (Luis do Nascimento Santos) é destacada, enquanto Virgilio Calegari teria apenas feito a ampliação das imagens para presentear o clube. Mais sobre o fotógrafo amador em: STUMVOLL, Denise Bujes. Fotografia e aproximações com a arte no início do século XX: um olhar para as narrativas visuais de Lunara. 2014. 209 f. Dissertação (Mestrado em Artes Visuais) - Programa de Pós-Graduação em Artes Visuais, Universidade Federal do Rio Grande do Sul, Porto Alegre, 2014. Disponível em: http://hdl. handle.net/10183/114657. Acesso em: 14 jul. 2019.
} 
Os uniformes dos dois clubes teriam, portanto, um padrão muito semelhante, ostentando listras, que chegaram aos esportes obedecendo "a códigos vizinhos aos das armas e bandeiras" (PASTOUREAU, 1993, p. 106), e se estabeleceram nesse campo, reaparecendo em roupas esportivas de várias modalidades, nos mais diversos países. Curiosamente, os uniformes da Blitz e da União eram repetidamente exigidos, as "cores sociais" ocasionalmente mencionadas, mas raramente se especificava quais seriam essas cores. Burke (2004) comenta que algumas coisas de cada época são tão sabidas que nos textos ficam silenciadas, restando às imagens fornecer informações que possibilitem preencher essas lacunas - tarefa dificultada ao se pesquisar em fotografias em preto e branco.

Embora não tenham sobrevivido documentos das sociedades que esclarecessem esse aspecto, foi possível determinar que a União usava azul e branco (LICHT, 2002; ROSE, 1952). O clube estabelecia suas regras em conformidade com as normas da Union Vélocipédique de France, e seria razoável que tivesse se espelhado também na instituição em termos de vestuário adequado para cada atividade dos ciclistas (LICHT, 2002; A FEDERAÇÃO, Porto Alegre, 7 maio 1900), assim como nos padrões e nas cores em voga entre os franceses, ou ainda se orientado por critérios mais próximos do lazer higiênico dos balneários.

A Blitz, por sua vez, vestia preto e amarelo (KOSERITZ' DEUTSCHE ZEITUNG, Porto Alegre, 27 abr. 1904). Diversas pesquisas em História do Esporte remetem às associações de origem teuto-brasileira como uma proposta de manutenção da cultura germânica - o que poderia influenciar, inclusive, na escolha das cores utilizadas nos uniformes. Os fundadores do clube de ciclismo participavam, inicialmente, de um clube de remo, que tinha as cores branca e encarnada (vermelha). Em 1903, a partir desses grupos, surgiria ainda um clube de futebol, que adotaria o verde e o branco (LICHT 2001; 2012). Partindo da hipótese que haveria uma conexão étnica, essas três combinações eram encontradas em brasões e bandeiras dos ducados e províncias germânicos. Entretanto, só em 1901 foi verificada uma aproximação entre a Blitz e outras sociedades "alemãs" - data posterior ao aparecimento dos uniformes. Dessa forma, outra possibilidade seria menos vinculada a uma questão de exaltação das origens e mais à funcionalidade - se as cores da União já estavam estabelecidas quando a Blitz escolheu as suas, é concebível que tenham optado por um padrão contrastante, que facilitasse o reconhecimento da afiliação dos competidores. Como exemplo de uma ideia semelhante, em 1903, a própria Blitz organizou uma corrida de resistência de seis horas, na qual bonés coloridos amarelo, preto/azul, branco, encarnado, preto/amarelo e preto - diferenciavam os corredores na contagem de voltas (A FEDERAÇÃO, Porto Alegre, 27 nov. 1899).

Outros meios foram empregados para distinguir os ciclistas da União - fitas encarnadas marcavam os seniors, enquanto verdes, os juniors, e os campeões poderiam ainda disputar uma braçadeira, um "significativo emblema" -, "o brassard, que consta de um parallellogrammo de damasco de seda azul escuro com o dizer: 'vos desafio' cercado de uma silva, bordados a prata" (SANTUCCI, 2016; A FEDERAÇÃO, Porto Alegre, 27 nov. 1899).

Voltando às roupas, o conjunto composto por camisas listradas, calças bufantes, bonés e polainas não era a única versão de uniforme conhecida pelos ciclistas porto-alegrenses. Em anúncios tanto da Blitz quanto da União, ocasionalmente havia a orientação para o uso do uniforme "sem paletó" durante préstitos e formalidades. Retratos, símbolos, hinos e cortejos eram - e ainda são, ao menos em âmbito profissional - solenidades comuns ao esporte amador daquela época. A exclusão do paletó em ocasiões formais é um aspecto inte- 
ressante, pois se afasta da ideia do uso de peças semelhantes na composição do traje formal masculino para outras ocasiões, e destacaria as listras e as cores dos clubes.

\section{FIGURAS 6 E 7: CICLISTAS DA UNIÃO VELOCIPEDICA DE AMADORES E RETRATO DE CARLOS BINA}
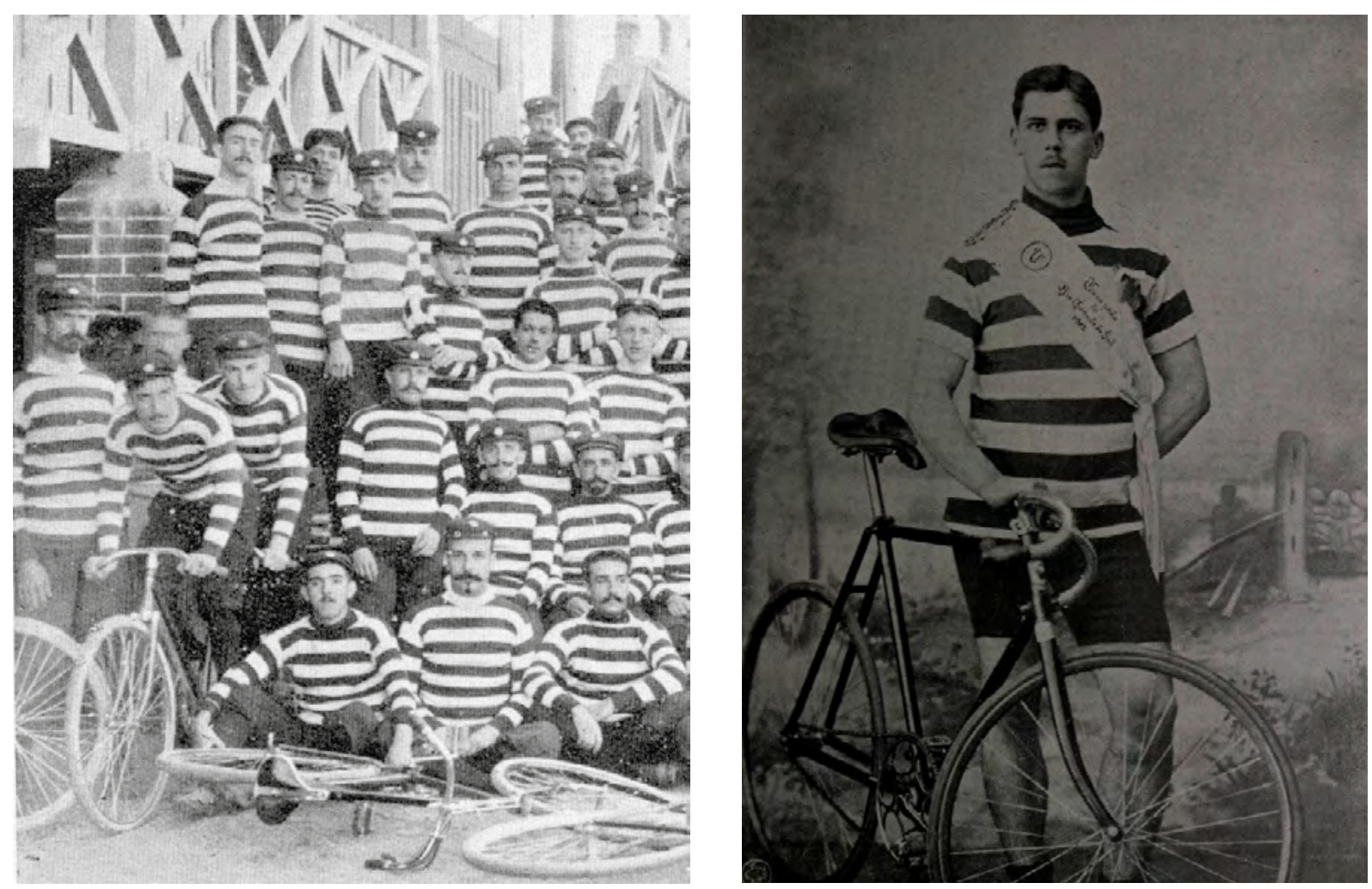

Fontes: STUDIO CALEGARI, [1899?], detalhe.

Acervo: Museu de Comunicação Social Hipólito José da Costa (MCSHJC).

Autor desconhecido, [1902?].

In: LEMOS, Antenor; CARVALHO, Edmundo G. Rio Grande do Sul sportivo.

Porto Alegre: Livraria do Globo, 1918, p.99. Acervo: Delfos/PUCRS.

Até onde se enxerga, os homens na fotografia em grupo cobrem suas pernas com polainas, seus braços com mangas longas e suas cabeças com bonés com distintivos, embora não atendam à recomendação de usar luvas. A maioria deles tem bigodes - os rostos lisos talvez sejam de rapazes mais jovens -, que eram um traço da aparência muito valorizado nesse período, conforme Souza (1987) e Feijão (2011). Apesar de não usarem paletós, o feitio desses uniformes aproxima-se do utilizado pelo clube alemão, retratado em 1885 (figura 4), e contrasta com o apresentado na imagem ao lado, o retrato de Carlos Bina, campeão da União em 1902. A camisa listrada permanece, mas Bina exibe os braços, os cabelos e as pernas, e seu calção ajustado é consideravelmente diferente do que os demais sócios vestem. Embora nenhum comentário sobre esse conjunto tenha sido localizado, também foi visto em periódicos europeus da época e, possivelmente, era utilizado apenas em corridas, por sua funcionalidade. 
A codificação dos uniformes carrega um traço tradicional ao emular características militares, mas, de maneira geral, os valores simbólicos da indumentária masculina de ciclismo alinhavam-se aos da modernidade, tornando seus corpos dinâmicos feito as máquinas, tão apreciadas naquele momento. Estavam bastante atualizados em relação aos europeus e, ainda quando se distanciavam da elegância formal do período, contavam com a valorização de uma nova elegância esportiva, também destacada no vestuário feminino.

Considerando os retratos como solenidades de então, notam-se múltiplos sentidos nessas imagens - simultaneamente ao vestuário moderno e à aparência geral, alinhada com o que era socialmente prezado, há a seriedade dos rostos e o olhar de alguns dos ciclistas para fora do quadro, protocolos da fotografia do século, que esses rapazes talvez não estivessem dispostos a contrariar. Pode-se imaginar que os novos hábitos eram a defesa da modernidade, enquanto as convenções mantidas seriam os pontos de contato com o que era consolidado e ainda valorizado.

\section{Senhoras correctamente trajadas}

Foi visto que, na época das draisianas e dos velocípedes, houve mulheres interessadas nos novos veículos. Com o advento das "bicicletas seguras", no fim do século, a situação não foi diferente. A recepção dessas novidades no Brasil foi dotada de analogias e discrepâncias tanto em relação à Europa quanto entre as capitais brasileiras observadas. Melo e Schetino (2009) comentam que vários motivos podem ter causado a diferença percebida na relevância do ciclismo para as mulheres "em países nos quais os sentidos e significados da modernidade pioneiramente começaram a ser construídos, como nos Estados Unidos, França e Inglaterra" (MELO; SCHETINO, 2009, p. 130). Para as estadunidenses, por exemplo, a bicicleta representou "uma estratégia de ampliar sua mobilidade e suas vivências públicas" (MELO; SCHETINO, 2009, p. 119-120), tendo importância no campo do lazer e na contestação dos papéis sociais que lhes eram atribuídos, sendo emblemática a volta ao mundo empreendida por Annie "Londonderry" Kopchovsky. A ciclista viajou entre 1894 e 1895 e

foi adotando trajes masculinos, que facilitavam seu desempenho, e angariando recursos com a venda de suas fotos ou de espaços em sua roupa para anunciantes, que ansiavam por ligar seu nome a uma iniciativa que ganhava repercussão em todos os locais nos quais Annie passava. (MELO; SCHETINO, 2009, p. 121)

No Rio de Janeiro, as práticas esportivas tiveram importância para as mulheres, ainda que no turfe e no ciclismo, por exemplo, tenham se envolvido sobretudo como espectadoras - as que se apresentaram como jóqueis ou ciclistas causavam estranhamento, não sendo completamente aceitas. 0 "caráter familiar" dos eventos esportivos também era destacado - "o papel da família continuava valorizado no novo contexto sociocultural" (MELO; SCHETINO, 2009, p. 124). Em São Paulo, a presença feminina no Velódromo Paulista era expressiva, embora sempre em grupos familiares, nunca sozinhas. Apesar disso, menos de dois anos depois da fundação da pista, algumas moças pedalavam por ali e até apostavam corridas, 
mesmo que a primeira corrida feminina "oficial" só fosse acontecer em 1903, quando "três moças disputaram um páreo de setecentos metros durante festa recreativa” (A PLATÉA, 23 mar. 1903, citada por GAMBETA, 2013, p. 84). Em Porto Alegre, nota-se algo semelhante: as primeiras vezes que se mencionou a presença feminina ou a frequência familiar no âmbito do ciclismo foi em 1898, decorrente da abertura da primeira pista de corridas. No ano seguinte, com a inauguração do velódromo da União Velocipedica, foi realizada a primeira corrida feminina "oficial", o páreo Gracil, que teve um percurso de 666 metros (duas voltas) e foi “disputado pelas senhoritas Josephina Corrêa, Nenê Fischer e Mimi Heredia” (LICHT, 2002, p. 45). Nenê Fischer, por exemplo, era sobrinha de Gustavo Maynard, que presidiu a União mais de uma vez (LICHT, 2002). Essa relação exemplifica os vínculos familiares entre os membros e as mulheres que frequentavam os clubes. Quanto à figura 8, com pessoas de sexos opostos, é cabível supor que seriam um casal de sócios, ou que estariam justamente em um contexto de aproximação visando um futuro matrimônio, como era aceitável nesses espaços. Outra hipótese é que fossem José Leite de Almeida e Josephina Barth, um proeminente ciclista, designado a portar o estandarte nos festejos de inauguração do velódromo, e a sócia honorária que o confeccionou (A FEDERAÇÃO, Porto Alegre, 20 nov. 1899; 18 dez. 1899). No estandarte aparecem as letras UV sobrepostas, no mesmo feitio da insígnia que o clube marcava seus anúncios no jornal (também visível na figura 11).

\section{FIGURA 8 - UM TRICICLO ORNAMENTAL PARTICIPANTE DE UM CORTEJO ESPORTIVO}

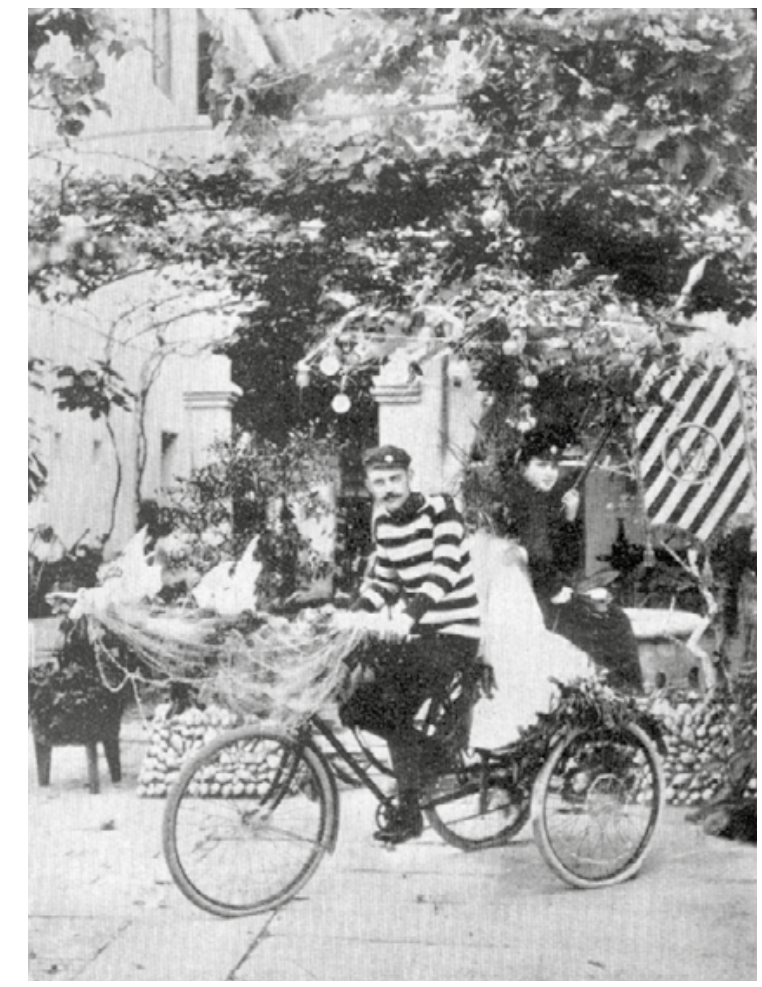

FONTE: Autor desconhecido, [1899?]. In: SCHIDROWITZ, Léo Jerônimo; FRANCO, Álvaro; SILVA, Morency de Couto e (Orgs.). Pôrto Alegre: biografia duma cidade: monumento do passado, documento do presente, guia do futuro. Série: Brasilia Aeterna. Porto Alegre: Tipografia do Centro, 1940. Acervo: MCSHJC. 
Na ocasião, destacou-se ainda que "entre os cyclistas das duas sociedades figuravam muitas senhoras correctamente trajadas com as côres das respectivas sociedades e pedalando com a maxima correcção e elegancia" (A FEDERAÇÃO, Porto Alegre, 20 nov. 1899). Apesar disso, nenhuma formalização de um uniforme para essas mulheres foi encontrada.

\section{FIGURA 9 - INAUGURAÇÃO DO VELÓDROMO DA UNIÃO}

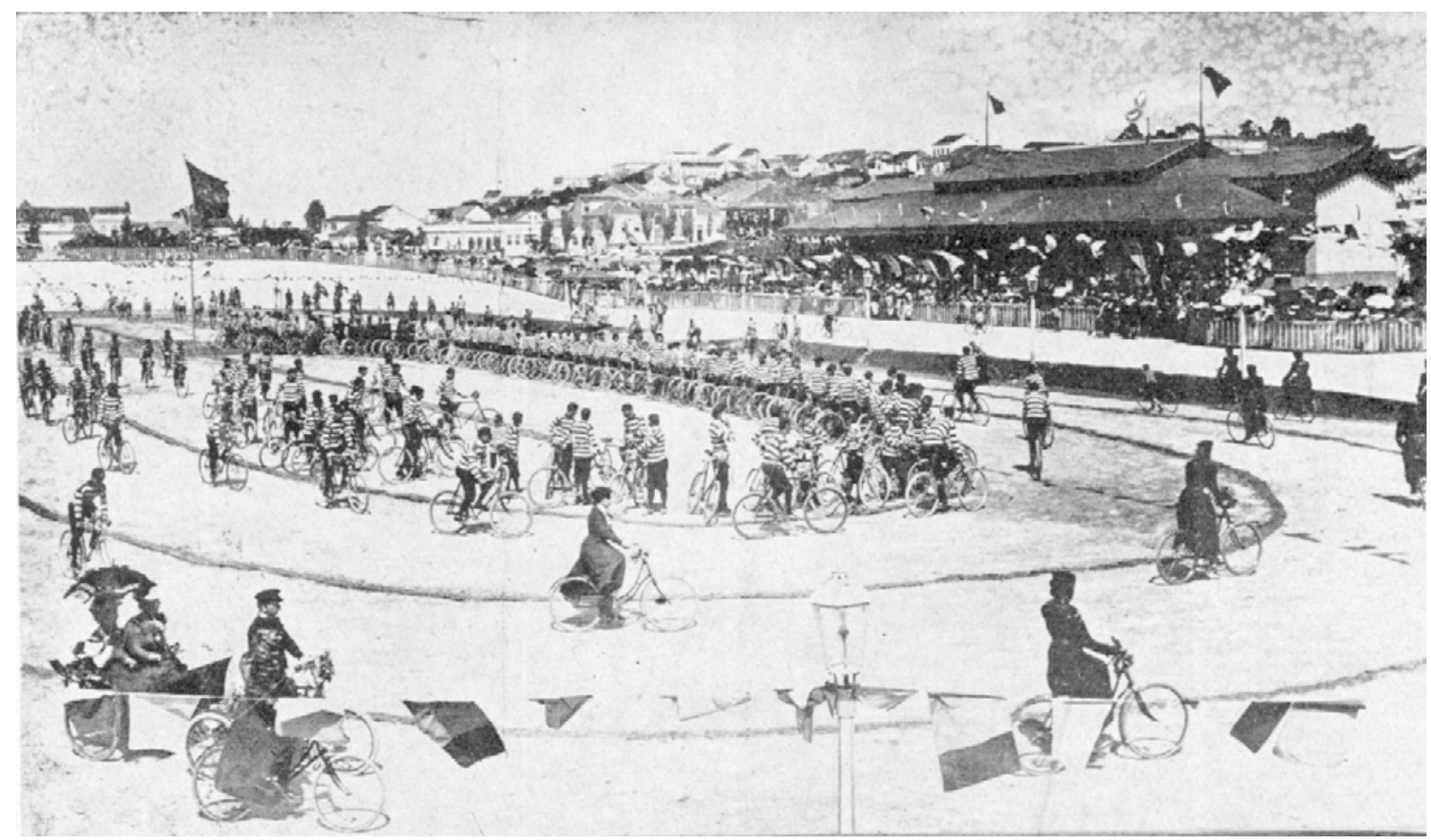

FONTE: LUNARA [?], [1899]. Revista do Globo, v. 8, n. 190, p. 15, Porto Alegre, 5 set. 1936. Acervo: Delfos/PUCRS.

A fotografia aparentemente foi tirada do alto da curva, e é impossível calcular quantos ciclistas estão enfileirados no centro da pista - contudo, são visíveis nove mulheres pedalando, em primeiro plano, em trajes escuros, como a moça no triciclo. De acordo com Laver, "as roupas esportivas femininas eram em geral pesadas, feitas de tecido rústico ou tweed, sendo as cores normalmente escuras" (LAVER, 1989, p. 209). Somando essa imagem ao retrato e à ilustração a seguir, é possível inferir que houvesse, de fato, uma versão feminina do uniforme da União, ainda que não oficial. No retrato, uma blusa de tricô, com listras largas, e bastante semelhante às utilizadas pelos homens do clube, é percebida. 0 chapéu, que lembra um boné militar, ostenta o distintivo da União. A ciclista veste uma saia, ou saia-calça, e está com luvas de couro. Além de um broche, que poderia ser um símbolo do próprio clube, o traje não tem enfeites - a pouca ornamentação era mais um aspecto recomendado para roupas esportivas (A FEDERAÇÃO, Porto Alegre, 17 ago. 1899). Também os cabelos mantidos presos, conforme era adequado às moças mais velhas e às mulheres adultas. 


\section{FIGURA 10 - SENHORA PORTO DA ROCHA [?] E DISTINTIVO NO DETALHE}
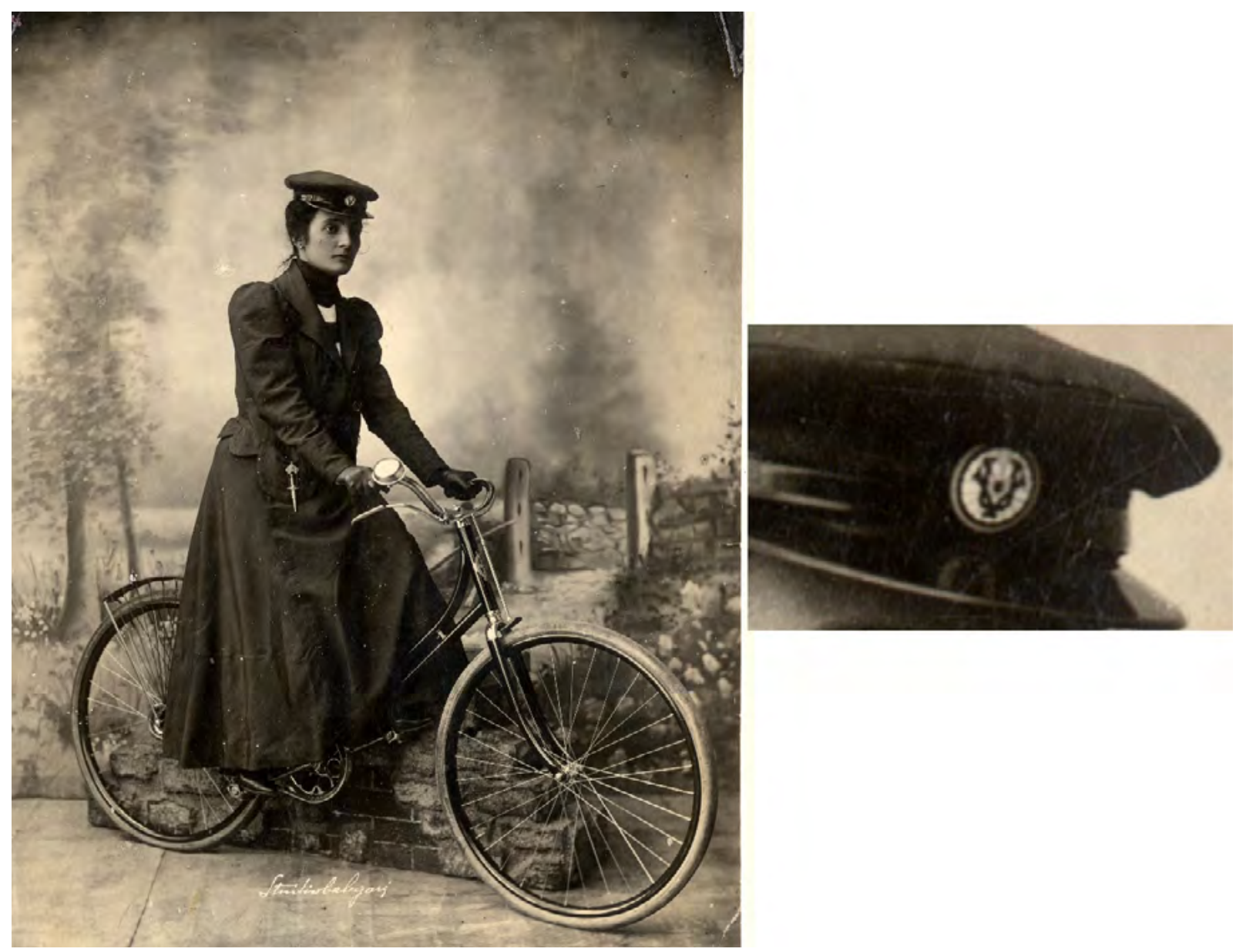

FONTE: Studio Calegari , [c.1899-1901]. Fototeca Sioma Breitman (MPAJJF).

A despeito de críticas quanto à imoralidade ou à masculinização que poderiam advir do uso da bicicleta por mulheres, Benjamin pontua um aspecto interessante:

Nestes salões [espaços fechados onde se aprendia a pedalar] a figura da mulher assumiu seu aspecto mais sedutor: como ciclista. [...]

A mulher como ciclista compete com a cantora de cabaré pelo lugar de honra em cartazes, e fornece para a moda a sua linha mais ousada. (BENJAMIN, 1982, p. 62-63, tradução minha) ${ }^{10}$

\footnotetext{
${ }^{10}$ Tradução minha para "In these halls the figure of the woman assumed its most seductive aspect: as cyclist. [...] The woman as cyclist competes with the cabaret singer for the place of honor on posters, and gives to fashion its most daring line" (BENJAMIN, 1982, p.62-63).
} 
De fato, a figura feminina aparece largamente representada como ciclista na publicidade e em diversas outras ilustrações do período - em contraponto à "desmaterialização" de décadas anteriores, talvez a corporificação dessas personagens, simultaneamente à provocação dos símbolos de feminilidade e masculinidade embaralhados, resultasse em um novo espectro de sensualidade.

A capa da partitura do hino composto para a inauguração do velódromo da União destaca a figura de uma ciclista - entretanto, apenas às vésperas da inauguração do espaço, algumas moças, que se destacaram nos preparativos, como Josephina Bath, foram admitidas como sócias honorárias.

Santos (1997) menciona que sapatos apontando sob a saia configuram um signo erotizador por manifestar inconscientemente a corporeidade - no movimento da pedalada, as ciclistas que optassem por saias, como a da figura 10, mostrariam seus pés de relance. Seria plausível que houvesse um traço de sensualidade implícito em todo esse contexto da prática física, e, ainda que as relações familiares ou matrimoniais mediassem o acesso dessas mulheres aos clubes, elas estariam experimentando um tipo de sociabilidade e um vestuário muito próprios de seu tempo.

FIGURA 11 - CAPA DA PARTITURA PARA PIANO DO

HINO DA UNIÃO VELOCIPEDICA DE AMADORES

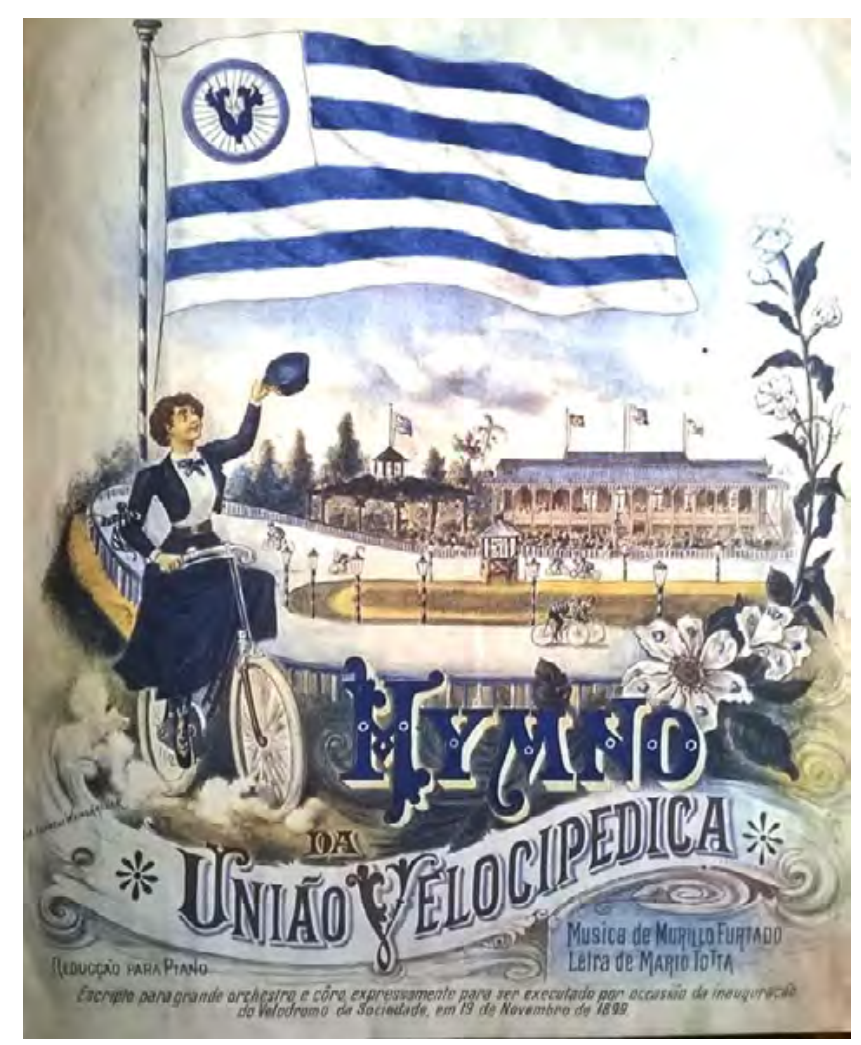

FONTE: Litografia Weingärtner [?], c.1899.

Essas moças ciclistas podem ter obtido referências para seus trajes tanto por meio de periódicos do centro do país quanto de estrangeiros - podendo, inclusive, ter importado as roupas. Dessa forma, os trajes com knickerbockers não passaram despercebidos às porto-alegrenses. 
Apesar de as moças já terem utilizado calções de ginástica para pedalar cerca de duas décadas antes, no Hemisfério Norte, esses calções causaram quase tanta controvérsia quanto o traje de Amelia Bloomer - "foram ridicularizados na imprensa e denunciados no púlpito, mas foi tudo em vão; as jovens continuaram a usá-los" (LAVER, 1989, p. 209). Crane sintetiza alguns tópicos:

O uso de calças [por mulheres] era particularmente controverso no século XIX, pois a ideologia da época estipulava identidades de gênero fixas e enormes diferenças - físicas, psicológicas e intelectuais - entre homens e mulheres. 0 ponto de vista dominante não deixava espaço para ambiguidades na identificação sexual e não abria nenhuma possibilidade de evolução ou mudança nos comportamentos e atitudes estabelecidos para os contingentes de cada gênero. (CRANE, 2009, p. 228)

Apesar disso, e de o número de mulheres ciclistas não ser tão alto em nenhuma das regiões observadas, buscou-se regulamentar o uso dos trajes, transitando entre aspectos diversos, entre os quais a medicina e a elegância. Até mesmo questões legais tiveram alterações na França, quando uma lei que proibia o uso de calças por mulheres flexibilizou-se, autorizando o uso para a prática do ciclismo, em 1892 (CRANE, 2006). Dois anos depois, a revista americana Harper's Bazar publicava uma imagem do traje de ciclismo com "calças turcas" - mas o modelo teve uma recepção mais controversa do que na Europa (SANTUCCI, 2016). Um episódio de rejeição acalorada foi registrado também no Rio de Janeiro:

A cousa, porem, tomou mais graves proporções. Uma chusma de garotos começou a vaiar a moça, perseguindo-a mesmo, procurando inutilisar-lhe a bicycleta e obrigando-a por fim a refugiar-se no encilhamento e a fugir do prado a toda velocidade da elegante machina que montava. (O PAIZ reproduzido em A BICYCLETA, São Paulo, 8 nov. 1896, n. 18, p. 72)

Na imprensa porto-alegrense, por outro lado, foi localizada apenas uma manifestação de desgosto pelo traje - um texto originalmente publicado pelo jornal $O$ Paiz (RJ) foi repetido pelo Correio do Povo (RS), em dezembro de 1897. Nele, um médico chamado Carlos Seidl lamentava a masculinização do vestuário. Houve ainda uma recomendação n'A Federação que se devia dar preferência para as saias - ainda que o jornal admitisse que a peça poderia enfunar e, por isso, as moças deveriam prender moedas de chumbo à barra (LICHT, 2002; A FEDERAÇÃO, 17 ago. 1899, p. 2).

Apesar de não serem vistas usando calções na inauguração do velódromo, moças foram retratadas pelo mais prestigiado fotógrafo de Porto Alegre vestindo a peça. 

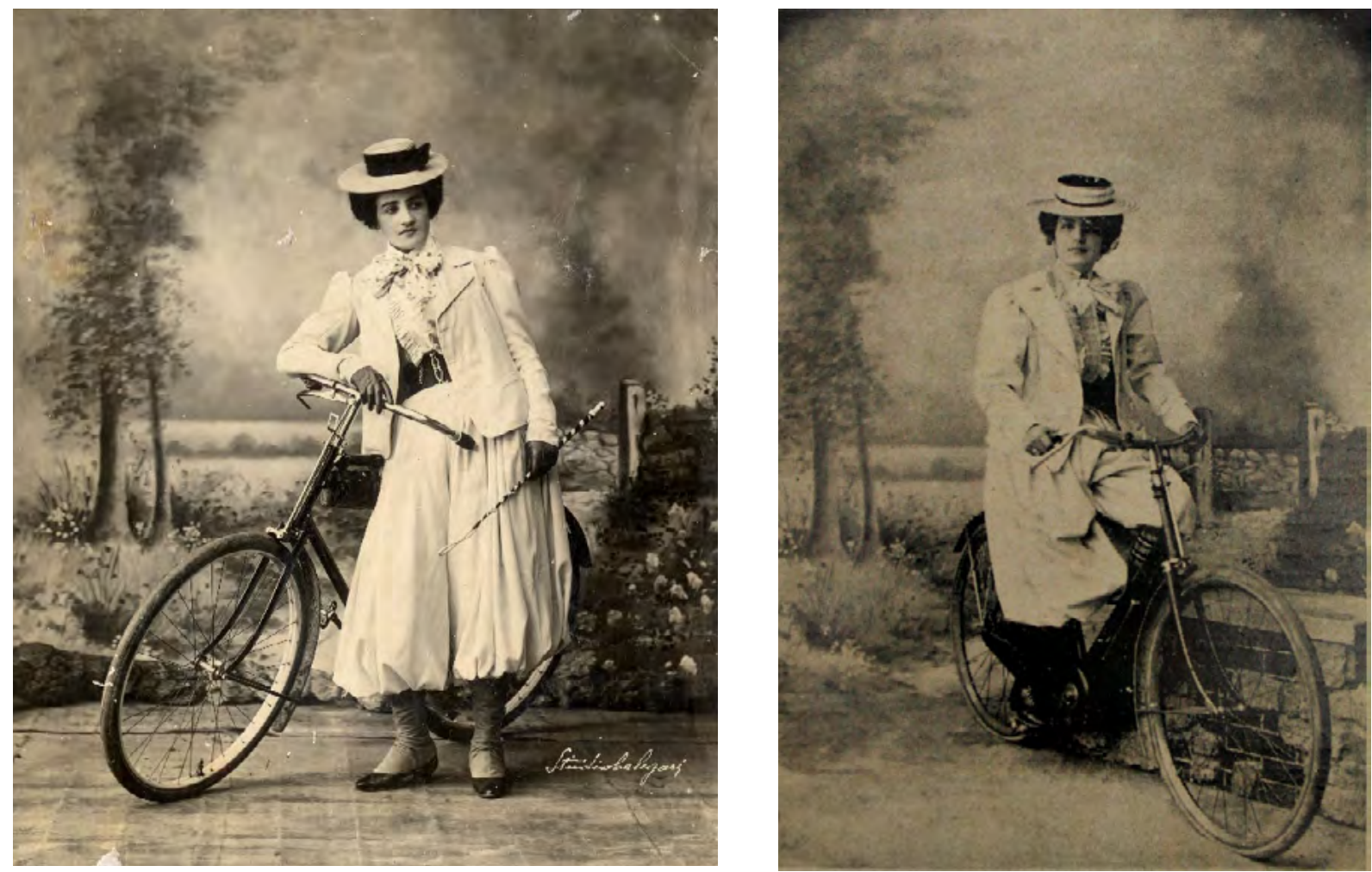

Fontes: STUDIO CALEGARI, [c.1899-1901]. Acervo: Fototeca Sioma Breitman (MPAJJF).

STUDIO CALEGARI, [c.1899-1901]. In: SCHIDROWITZ, Léo Jerônimo et al. (Orgs.). Rio Grande do Sul: imagem da terra gaúcha: a obra documentária do estado sulino, fronteira extrema do Brasil. Porto Alegre:

Cosmos, 1942, p. 131.

Talvez a sensibilidade local, apesar da filosofia positivista a qual aderiram as elites, tenha conseguido administrar e ressignificar a presença feminina no ciclismo e sua indumentária, inclusive os knickerbockers, pois desde muito tempo já se via, em regiões próximas, mulheres que, para ir à igreja aos domingos, montavam a cavalo como os homens, vestindo uma calça branca fina e acomodando seus vestidos na altura da cintura (FERREIRA, 1957).

Por fim, outra peça do traje para ciclismo que chegou à cidade, acompanhada de prescrições de uso, foi o espartilho. Alguns estudiosos reforçam a ideia de uma suposta libertação dos corpos femininos causada pela prática esportiva. Outros, dão os créditos dessa "libertação" ao costureiro Paul Poiret. Contudo, em concordância com Elizabeth Wilson, "nenhum indivíduo provocou essa mudança" (WILSON, 2003, p.40, tradução minha) ${ }^{11}$. A autora defende que a autoproclamação de Poiret, e a adesão a ela, personaliza e simplifica em excesso uma mudança gradual. Acrescenta ainda que os espartilhos não desapareceram, mas

${ }^{11}$ Tradução minha para "No one individual brought about this change" (WILSON, 2003, p.40). 
eventualmente teriam evoluído para os modeladores elásticos, como as cintas, populares nos anos 1950 (WILSON, 2003).

No fim do século XIX, ingleses e americanos produziam espartilhos em massa, com variedade de estilos e tamanhos padronizados, para diferentes idades, tipos de corpo e atividades, incluindo os esportes (STEELE, 2007).

Como os esportes se tornaram mais populares, a publicidade de espartilhos focou-se cada vez mais em modelos especializados para passeios a cavalo ou de bicicleta, que tendiam a ser mais flexíveis, com quadris recortados e nesgas elásticas. A publicidade é, obviamente, caracterizada por um considerável grau de exagero e absoluta duplicidade, assim como por tentativas de criar desejos de consumo. (STEELE, 2007, p. 56, tradução minha) ${ }^{12}$

Steele (2007) apresenta um anúncio da americana W.B. Corsets que destaca a "liberdade total" (perfect freedom), garantida pelas faixas elásticas da peça. É possível que esses modelos mais maleáveis tenham sido acompanhados por uma flexibilização também em seu uso. Como as demais peças, atendia a prescrições - em um manual chamado Bicycle for Ladies, estabelece-se que "um espartilho, se for usado, não deve se estender abaixo da linha da cintura, e deve ter cordame lateral elástico" (WARD, 1896, p. 98, tradução e grifo meus) ${ }^{13}$. Em Porto Alegre, o jornal A Federação chama a peça de collete e endossa a importância da maior flexibilidade em sua orientação:

Collete e véu - Os únicos espartilhos permitidos são os conhecidos sob as denominações <<espartilhos de verão >> e <<espartilhos de gravidez>>, nos quaes as barbatanas em pequeno numero e flexiveis são reunidas por um tecido aberto do genero de talagarça. Não tendo outro fim sinão endireitar o busto e preservar o corpo da prisão dos cordões da saia, o espartilho das cyclistas não deve ser muito apertado. As fitas que seguram as meias deverão ser presas n'elle [...]. (A FEDERAÇÃO, Porto Alegre, 17 ago. 1899, p. 2, grifos meus)

\footnotetext{
${ }^{12}$ Tradução minha para "As sports became more popular, corset advertising increasingly focused on specialized models for horseback riding or bicycling, which tended to be more flexible with cutaway hips and elastic gores. Advertising is obviously characterized by considerable degree of exaggeration and outright duplicity, as well as attempts to create consumer desires" (STEELE, 2007, p. 56).

${ }^{13}$ Tradução minha para "A corset, if one is worn, should not extend below the waist-line, and should have elastic side-lacing” (WARD, 1896, p.98).
} 
Em novembro de 1899, o ano que a prática parece ter sido mais popular entre as moças, espartilhos para ciclistas eram destacados em um anúncio na Koseritz' Deutsche Zeitung:

\section{FIGURA 14 - ANÚNCIO DE CORSETS MADAME JACOMETTI}

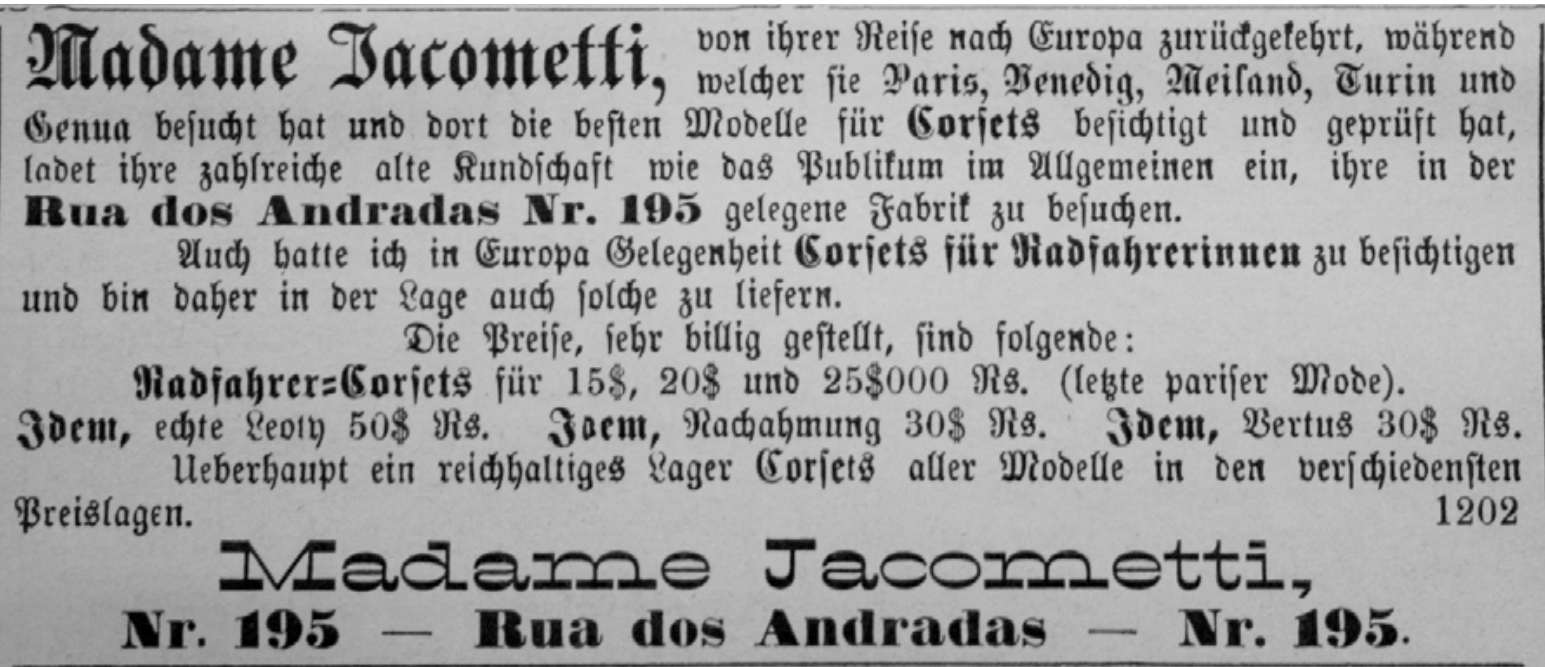

FONTE: Koseritz' Deutsche Zeitung, 14 nov. 1899, n. 91, p. 3.

Madame Jacometti afirmava, em seu anúncio, ter tido a oportunidade de ver na Europa os espartilhos para ciclistas (Corsets für Radfahrerinnen), última moda em Paris (letzte pariser Mode), e que os estava fornecendo.

Dessa forma, vemos que, além da camada externa, as ciclistas de Porto Alegre possivelmente estavam atualizadas também quanto à roupa de baixo. Quanto à "libertação do corpo feminino", embora os esportes tenham desempenhado o papel de catalisadores para a aceitação de peças mais práticas e confortáveis no cotidiano, a questão permanece pontuada por avanços e retrocessos, diversas nuances que não terão espaço para ser debatidas aqui, mas que podem ser exemplificadas pelo retorno dos espartilhos no fim do século XX, bastante ressignificados, não mais utilizados apenas como roupa de baixo e inseridos em um contexto de modificação corporal - que pode ser vista como a apropriação e a libertação do próprio corpo levadas a outro patamar.

\section{Desenlace}

Recapitulando brevemente, pode-se apontar que houve ao menos três grandes momentos para os veículos de duas rodas no século XIX - no fim dos anos 1810, no fim dos anos 1860 e entre os anos 1880 e 1890, sendo este último o mais impactante e duradouro. Nos três momentos, nota-se que foi estabelecida uma relação entre o veículo e a roupa do usuário - destacadamente, a das usuárias. Em alguns momentos, o próprio veículo foi alterado para que as roupas não precisassem ser trocadas. Em outros, roupas de ginástica, ou que obedeciam à mesma noção de mobilidade corporal, foram adotadas pelos ciclistas. 
Com a emergência dos clubes, além das codificações estabelecidas pela saúde e pela elegância, as identidades desses grupos vincularam-se a uniformes e outros símbolos. As práticas físicas ganhavam ou perdiam atenção conforme eram percebidas como "esportes da moda". 0 entusiasmo do público feminino por essas atividades distendeu os limites quanto ao que lhes era permitido, tanto em termos de roupas quanto em vivência de experiências profundamente imbricadas com a modernidade, ainda que concepções tradicionais permeassem todas essas novidades.

Não surpreende, dessa forma, que, em pouco tempo, a dança despontasse como uma nova febre em um cenário em que, física e metaforicamente, ideias e produtos se moviam cada vez mais depressa - trajetórias interessantes de se observar em um momento futuro.

\section{Referências}

A BICYCLETA: semanario cyclistico ilustrado. São Paulo, 1896-?.

ACKERMANN, Rudolph. Repository of arts, literature, fashions and politics. Ser. 2, v. 7, jan.-june 1819. Disponível em: https://hdl.handle.net/2027/nyp.33433081657706. Acesso em: 14 jun. 2019.

A FEDERAÇÃO: orgão do Partido Republicano. Porto Alegre, 1884-1937.

BENJAMIN, Walter. The arcades project. Tradução (inglês) Howard Eiland e Kevin McLaughlin. Cambridge/Londres: Harvard University Press, 2002. Preparado com base no volume alemão Das Passagen-Werk (1982), editado por Rolf Tiedemann.

BOUCHER, François. História do vestuário no Ocidente: das origens aos nossos dias. Edição ampliada por Yvonne Deslandres. Tradução André Telles. São Paulo: Cosac Naify, 2010.

BURKE, Peter. Testemunha ocular: história e imagem. Tradução Vera Maria Xavier dos Santos. Revisão técnica Daniel Aarão Reis Filho. Bauru: EDUCS, 2004.

CARDOZA, Thomas. Intrepid Women: cantinières and vivandières of the French Army. Bloomington: Indiana University Press, 2010.

CRANE, Diana. A moda e seu papel social: classe, gênero e identidade das roupas. Tradução Cristina Coimbra. São Paulo: Editora Senac São Paulo, 2006.

ELIAS, Norbert. 0 processo civilizador. Volume II - Formação do estado e civilização. 2. ed. Tradução Ruy Jungman. Revisão e apresentação Renato Janine Ribeiro. Rio de Janeiro: Jorge Zahar Editor, 1994. 
FEIJÃO, Rosane. Moda e modernidade na belle époque carioca. São Paulo: Estação das Letras e Cores, 2011.

FERREIRA, Athos Damasceno. Apontamentos para o estudo da indumentária. In: FERREIRA, Athos Damasceno et al. Fundamentos da cultura rio-grandense. 2. série. Porto Alegre: Faculdade de Filosofia/UFRGS, 1957.

GAMBETA, Wilson Roberto. A bola rolou: o velódromo paulista e os espetáculos de futebol (1895/1916). 2013. 408 f. Tese (Doutorado em História Social) - Faculdade de Filosofia, Letras e Ciências Humanas, Universidade de São Paulo, São Paulo, 2014. Disponível em: http://www.teses.usp.br/teses/disponiveis/8/8138/tde-01102014-162931/. Acesso em: 5 jul. 2016.

HERLIHY, David V. Bicycle: the history. New Haven: Yale University Press, 2004.

KOSERITZ’ DEUTSCHE ZEITUNG. Porto Alegre, 1881-1906.

LAVER, James. Historical introduction. In: BARNEY, Sydney D. Clothes and the horse: a guide to correct dress for all riding occasions. Londres: Vinton \& Company, 1953.

LAVER, James. A roupa e a moda: uma história concisa. Capítulo final [por] Christina Probert. Tradução Glória Maria de Mello Carvalho. São Paulo: Companhia das Letras, 1989.

LEMOS, Antenor; CARVALHO, Edmundo G. Rio Grande do Sul sportivo. Porto Alegre: Livraria do Globo, 1918.

LICHT,Henrique Felippe Bonnet. Ruder-Verein Germânia, 1892-1917: subsídios históricos. 4 jun. 2001. Documentos diversos. Disponível em: http://hdl.handle.net/10183/71083. Acesso em: 19 out. 2016.

LICHT, Henrique Felippe Bonnet. Ciclismo no Rio Grande do Sul: 1869-1905. Porto Alegre: Centro de Memória do Esporte da Escola de Educação Física/UFRGS, 2002. Disponível em: http://hdl.handle.net/10183/79679. Acesso em: 9 fev. 2015.

LICHT, Henrique Felippe Bonnet Futebol: subsídios históricos. 24 jul. 2012. Documentos diversos. Disponível em: http://hdl.handle.net/10183/94953. Acesso em: 19 out. 2016.

LIPOVETSKY, Gilles. 0 império do efêmero: a moda e seu destino nas sociedades modernas. Tradução Maria Lucia Machado. São Paulo: Companhia das Letras, 2009.

MELO, Victor Andrade de. Corpos, bicicletas e automóveis: outros esportes na transição dos séculos XIX e XX. In: PRIORE Mary del; MELO, Victor Andrade de (Org.). História do esporte no Brasil: do império aos dias atuais. São Paulo: Editora UNESP, 2009. 
MELO, Victor Andrade de; SCHETINO, André. A bicicleta, o ciclismo e as mulheres na transição dos séculos XIX e XX. Revista Estudos Feministas, Florianópolis, v. 17, n. 1, p.111134, 2009. Disponível em: http://www.scielo.br/scielo.php?script=sci_arttext\&pid=S0104026X2009000100007\&lng=en\&nrm=iso. Acesso em: 31 jul. 2016.

MILLER, Christopher M.; MCINTYRE, Shelby H.; MANTALA Murali K. Toward Formalizing Fashion Theory. Journal of Marketing Research, Chicago, v. 30, n. 2, p.142-157, maio 1993. Disponível em: http://www.jstor.org/stable/3172824. Acesso em: 19 out. 2016.

PASTOUREAU, Michel. 0 pano do diabo: uma história das listras e dos tecidos listrados. Tradução Lucy Magalhães. Rio de Janeiro: Jorge Zahar Editor, 1993.

PINCH Trevor; BIJKER, Wiebe. The social construction of facts and artifacts: or how the sociology of science and the sociology of technology might benefit each other. In: BIJKER, Wiebe; HUGHES, Thomas Parke; PINCH Trevor (Eds.). The social construction of technological systems: new directions in the sociology and history of technology. Cambridge/Londres: The MIT Press, 2012.

ROCHE, Daniel. A cultura das aparências: uma história da indumentária (séculos XVIIXVIII). Tradução Assef Kfouri. São Paulo: Editora Senac São Paulo, 2007.

ROSE, Tulio de. 0 ground dos Moinhos de Vento. Fôlha da Tarde, Porto Alegre, 21 ago. 1952. Edição esportiva. Recorte.

SANTOS, Alexandre Ricardo dos. A fotografia e as representações do corpo contido (Porto Alegre 1890-1920). 1997. 2 v. Dissertação (Mestrado em Artes Visuais) - Instituto de Artes, Universidade Federal do Rio Grande do Sul, Porto Alegre, 1997.

SANTUCCI, Natália de Noronha. 0 elegante sport: conexões entre a moda, a modernidade e o ciclismo em Porto Alegre (1895-1905). 2016. 250 f. Dissertação (Mestrado em História) - Programa de Pós-Graduação em História, Pontifícia Universidade Católica do Rio Grande do Sul, Porto Alegre, 2016. Disponível em: http://tede2.pucrs.br/tede2/handle/tede/7075. Acesso em: 14 jul. 2019.

SCHETINO, André Maia. Pedalando na modernidade: a bicicletas e o ciclismo no Rio de Janeiro e em Paris na transição dos séculos XIX-XX. 2007.119 f. Dissertação (Mestrado em História Comparada) - Instituto de Filosofia e Ciências Sociais, Universidade Federal do Rio de Janeiro, Rio de Janeiro, 2007.

SCHIDROWITZ, Léo Jerônimo; FRANCO, Álvaro; SILVA, Morency de Couto e (Orgs.). Pôrto Alegre: biografia duma cidade: monumento do passado, documento do presente, guia do futuro. Série: Brasilia Aeterna. Porto Alegre: Tipografia do Centro, 1940. 
SCHIDROWITZ, Léo Jerônimo; SILVA, Morency de Couto e; PIRES, Arthur Porto; SANMARTIN, Afonso. (Orgs.) Rio Grande do Sul: imagem da terra gaúcha: a obra documentária do estado sulino, fronteira extrema do Brasil. Porto Alegre: Cosmos, 1942.

SEVCENKO, Nicolau. A capital irradiante: técnica, ritmos e ritos do Rio. In: SEVCENKO, Nicolau; NOVAIS, Fernando A. (Orgs.). História da vida privada no Brasil: República: da Belle Époque à Era do Rádio. v. 3. São Paulo: Companhia das Letras, 1991.

SENNETT, Richard. 0 declínio do homem público: as tiranias da intimidade. Tradução Lygia Araujo Watanabe. São Paulo: Companhia das Letras, 1988.

SOARES, Carmen Lúcia. As roupas nas práticas corporais e esportivas: a educação do corpo entre o conforto, a elegância e a eficiência (1920-1940). Campinas: Autores Associados, 2011.

SOUZA, Gilda de Mello e. 0 espírito das roupas: a moda no século XIX. São Paulo: Companhia das Letras, 1987.

STEELE, Valerie. The corset: a cultural history. 5. ed. New Heaven/Londres: Yale University Press, 2007.

SVENDSEN, Lars. Moda: uma filosofia. Tradução Maria Luiza X. de A. Borges. R. de Janeiro: Zahar, 2010.

WARD, Maria E. Bicycling for ladies. Nova York: Brentano’s, 1896.

WARNER, Patricia Campbell. When the girls came out to play: the birth of American sportswear. Amherst: University of Massachusetts Press, 2006.

WILSON, David Gordon. Bicycling science. 3. ed. Contribuições de Jim Papadopoulos. Cambridge/Londres: The MIT Press, 2004.

WILSON, Elizabeth. Adorned in dreams: fashion and modernity. Londres/Nova York: I. B. Tauris, 2003. 